Krzysztof Tarka

Opole

\title{
„Monitor Londyński” — krótki żywot pisma „zamkowych” legalistów
}

Po śmierci prezydenta Władysława Raczkiewicza w czerwcu 1947 r. emigrantów podzielił spór o obsadę stanowiska głowy państwa. Konkurentami do fotela prezydenckiego byli Tomasz Arciszewski, premier rządu, desygnowany w 1944 r. na następcę prezydenta, oraz August Zaleski, były minister spraw zagranicznych i urzędujący szef kancelarii cywilnej prezydenta, którego śmiertelnie chory Raczkiewicz w ostatnich tygodniach życia wyznaczył na swojego następcę. Zmiany tej nie uznał Arciszewski i jego stronnictwo - Polska Partia Socjalistyczna. Pozycja prezydenta i rządu uległa znacznemu osłabieniu, gdy w 1949 r. ,zamek” opuściło Stronnictwo Narodowe. W grudniu tego roku opozycyjne partie utworzyły Radę Polityczną. Wzajemne oskarżenia pogłębiły rozłam, w istotny sposób przyczyniając się do marginalizacji emigracji politycznej.

Nadzieje na ponowne zjednoczenie powszechnie wiązano z misją ostatniej szansy podjętą przez cieszącego się autorytetem i zaufaniem w środowiskach emigracyjnych generała Kazimierza Sosnkowskiego. W grudniu 1952 r. generał po raz pierwszy przybył z Kanady (gdzie osiedlił się w 1944 r.) do Londynu. Mediacja miała doprowadzić do zjednoczenia i dobrowolnego ustąpienia (tak, by ocalić legalizm) ze stanowiska prezydenta Augusta Zaleskiego. Następcę powszechnie widziano w Sosnkowskim.

Apogeum konfliktu przypadło na rok 1954. Mimo trzech wizyt generała w Londynie, niespodziewanego oświadczenia Zaleskiego o ustąpieniu z zajmowanego stanowiska po upływie siedmioletniej kadencji (faktycznie była to gra na zwłokę), a nawet podpisania przez zwalczające się grupy w marcu 1954 r. Aktu zjednoczenia - nie udało się osiągnąć jedności. Misja Sosnkowskiego zakończyła się klęską. Urzędujący prezydent nie zgodził się ostatecznie na wyznaczenie generała swoim następcą, wbrew własnej zapowiedzi nie ustąpił też z fotela prezydenckiego. 8 VI 1954 r. Zaleski złożył oświadczenie o pozostaniu na urzędzie. Dekompozycja „polskiego” Londynu stała się faktem. Ponowne rozbicie okazało się znacznie głębsze i trwalsze. $\mathrm{Na}$ wiele lat utrwaliło się formalne zdublowanie emigracyjnych władz. Konkurencyjnym wobec obozu prezydenckiego (,zamek”) ośrodkiem politycznym stała się utworzona w sierpniu $1954 \mathrm{r}$. Rada Trzech i Egzekutywa Zjednoczenia Narodowego (,Zjednoczenie”). W opozycji do prezydenta i rządu znalazła się zdecydowana większość emigracyjnych ugrupowań politycznych ${ }^{1}$.

\footnotetext{
${ }^{1}$ Szerzej zob. R. Habielski, Kryzysy prezydenckie 1947 i 1954 roku. Ich antecedencje i nastepstwa, w: Warszawa nad Tamiza. Z dziejów polskiej emigracji politycznej po drugiej wojnie światowej,
} 
W takich okolicznościach z datą 1 VII 1954 r. ukazał się „Monitor Londyński”. Pismo, zapowiadane jako dwutygodnik, miało być „wolną trybuną Polaków w wolnym świecie”. Jego redaktorem został Jerzy Zdzisław Kędzierski, a wydawcą Jerzy Ścibor. Obaj byli działaczami proprezydenckiego Konwentu Walki o Niepodległość. Redakcja deklarowała, że stoi na gruncie legalizmu, ,wiedząc dobrze, że wrogowie Polski różnymi drogami konsekwentnie dążą do zniszczenia władz Rzeczypospolitej na obczyźnie”. Emigracyjnej prasie zarzucano stronniczość, chwiejność i zależność od obcych pieniędzy. W tej sytuacji istniała „paląca konieczność wydawania pisma niezależnego, któreby odważnie i z otwartą przyłbicą dawało świadectwo polskiej prawdzie”. Takim pismem miał być „Monitor Londyński”. Na jego łamy zapraszano „każdego Polaka, z wyjątkiem komunistów i mikołajczykowców”2.

„Monitor Londyński” był organem zajadłych przeciwników zjednoczenia, bezkompromisowych obrońców legalizmu i żarliwych zwolenników prezydentury Augusta Zaleskiego. W pierwszym numerze autor ukrywający się pod pseudonimem „Nike” podkreślił, iż pozostanie prezydenta Zaleskiego na urzędzie było „wielkim zwycięstwem sprawy niepodległości”. „Zamach” przygotowywany przez oponentów Zaleskiego „został zniweczony”, a prezydent „uratował ciągłość prawną Państwa Polskiego”. Wypływającą z różnych stron krytykę postępowania Zaleskiego „Nike” przyrównał do zamachu na Gabriela Narutowicza: „Prezydent RP, którego w ostatnich tygodniach bergowcy, dżokeje polityczni i ludzie w błąd wprowadzeni złą propagandą obrzucali brudem w postaci uchwał, wieców i artykułów, tak jak błotem obrzucano przez endecję zamordowanego Prezydenta Narutowicza, okazał się człowiekiem silnym, godnym obrońcą Konstytucji, Prezydentem, który nie ugnie się przed żadnym naciskiem i polskiego honoru państwowego, stworzonego pracą i walką Józefa Piłsudskiego na szwank nie narazi” . Krytykując emigracyjne partyjniactwo, publicysta stwierdził: „Ten klucz partyjny, który dzisiaj w Akcie Zjednoczenia zmajstrowano, nigdy nie pasował do zamku zwanego Polską”. Zapowiadał, że „tym razem jednak słabość musi przegrać. Co lepsi i wartościowsi ludzie otrząsną się niedługo z psychozy «zjednoczeniowej», jaką podsycali bergowcy, dążący do tego, aby swoje krwawe brudy zakryć Majestatem Rzeczypospolitej”. Choć „dziś trwają jeszcze ataki na osobę Prezydenta RP”, to ,jutro posypią się doń adresy hołdownicze i słowa wdzięczności”,3.

W podobnym tonie pisał również Jerzy Z. Kędzierski. Redaktor „Monitora Londyńskiego", broniąc urzędu i osoby prezydenta Zaleskiego, dezawuował Akt zjednoczenia, „będący zwyrodniałą karykaturą pierwotnego projektu zamiarów gen. Sosnkowskiego”. Przekonywał, że podpisane niedawno porozumienie w istocie rzeczy było „spiskiem i zamachem na istnienie legalnych władz Rzeczypospolitej” oraz „na niezależność polskiej siły od obcych”. Miało ono jakoby na celu „osłonę bergowców przed odpowiedzialnością sądową i oddanie na zawsze władzy partyjnikom bez i poza kontrolą społeczeństwa oraz uzależnienie emigracji od pieniędzy amerykańskich i Mikołajczyka”. Demaskując emigracyjne ugrupowania, uważał, iż „,degeneracja partii politycznych jest zupełna”: „Przekupne, agenturalne, płatne, muszą być zwalczane przez społeczeństwo jako zło nr 2, gdyż wrogiem nr 1 są Sowiety i Mikołajczyk”. Jako żarliwy legalista podkreślił, iż „konstytucji [kwietniowej z 1935 r. — K. T.] należy trzymać się wiernie, bez żadnych interpretacji”. Krytykując „żółwie i ospałe tempo" działalności Skarbu Narodowego oraz słabe wyrobienie obywatelsko-polityczne „pewnych członków” jego prezydium, uważał, że instytucja ta powinna

red. A. Friszke, Warszawa 1994, s. 19-32; P. Ziętara, Misja ostatniej szansy. Próba zjednoczenia polskiej emigracji politycznej przez gen. Kazimierza Sosnkowskiego w latach 1952-1956, Warszawa 1995.

2 Od Redakcji, „Monitor Londyński” 1954, nr 1, s. 14.

${ }^{3}$ Nike, Zwycięstwo, ibidem, s. 2-4. 
zbierać na działalność emigracyjnych władz „najmniej milion funtów rocznie”. Postulował „wciąganie do pracy państwowej ludzi, którzy odchodzą i będą odchodzić od skorumpowanych kadłubów partyjnych oraz tych, którzy ostatnio uciekli z Polski i są wolni od sklerozy emigracyjnej, tej typowej choroby większości czcigodnych mężów, trzymających się kurczowo zgrzybiałymi rękami władzy w organizacjach politycznych". Uzdrowienie organizacji społecznych przynieść miał „dopływ ludzi z prowincji, ludzi z hosteli, fabryk i kopalń, na miejsce pasożytów, żerujących na ciele tych organizacji, tzw. urzędników społecznych, którzy piastują po kilka płatnych stanowisk" ${ }^{4}$.

W tym samym numerze „Monitora Londyńskiego” Juliusz Sokolnicki, członek Głównego Komitetu Wykonawczego Ligi Niepodległości Polski, skrytykował stanowisko kierownictwa swojej partii. Uważając się za ideowego piłsudczyka, zarzucił władzom LNP odejście od kierunku opartego na wskazaniach Marszałka. Sokolnicki twierdził, że przywódcy Ligi, szukając „koniecznie pozytywnego” rozwiązania sprawy zjednoczenia emigracji, skłonni byli pójść na „każdą ugodę, na każdy kompromis dla osiągnięcia nominacji gen. Sosnkowskiego na następcę Prezydenta RP”. Zarzucał kierownictwu LNP, że nie doceniając konieczności konsolidacji obozu legalistycznego, skupionego wokół prezydenta Zaleskiego, marzyło „o wytworzeniu jakichś innych sojuszów czy układów, nawet kosztem zasad, o które tyle lat z powodzeniem się walczyło”. Apelował też „o otrzeźwienie, spojrzenie wstecz na smutny dorobek paru ostatnich miesięcy i powrót na drogę jedynie dla Piłsudczyków możliwą, drogę pracy państwowej i wierności Konstytucji i Prezydentowi Rzeczypospolitej"5. Jego artykuł był zapowiedzią frondy w LNP.

Secesjoniści 30 VI 1954 r. utworzyli Konwent Walki o Niepodległość. Organizacja miała mieć charakter ponadpartyjny. Członkowie Konwentu stali bez zastrzeżeń u boku prezydenta Zaleskiego i kategorycznie sprzeciwiali się zjednoczeniu z Radą Polityczną („,bergowcami”). Prezesem nowego ugrupowania został Jerzy Ścibor, wiceprezesami: Stanisław Pomianowski i Jerzy Z. Kędzierski, sekretarzem generalnym Juliusz Sokolnicki, skarbnikiem Tadeusz Deiholos. W depeszy skierowanej do Zaleskiego działacze Konwentu złożyli mu „hołd” oraz „wyrazy najgłębszej wdzięczności za nieugiętą postawę w obronie najżywotniejszych praw Narodu i Państwa”. Zapewniali prezydenta, że będą „stać przy legalnych Władzach Rzeczypospolitej, bez względu na tak zwaną opinię, dziś celowo w błąd wprowadzaną". Decyzja Zaleskiego o pozostaniu na urzędzie, ,mimo nacisku sił wrogich obcych i polskich”, była dla nich ,wezwaniem do podjęcia akcji politycznej",

Redakcja „Monitora Londyńskiego” oskarżała „sprzedajnych” działaczy Rady Politycznej o zmarnowanie międzynarodowej koniunktury, jaką przed kilku laty stworzyła zapowiadana przez generała Dwighta Eisenhowera podczas kampanii wyborczej w Stanach Zjednoczonych polityka „wyzwolenia”. Według zwolenników Zaleskiego Polska „mogła zagrać jako czynnik wielkiej wagi w polityce wyzwolenia”. Jednak ,przekupni partyjnicy” z Rady Politycznej skoncentrowali się na wściekłych atakach ,na osobę i instytucję Prezydenta RP, na tę ostatnią twierdzę, jaką Polska Niepodległa posiada”. W efekcie: „Zamiast stać się partnerem Ameryki, w miejsce Niemiec, zostaliśmy zepchnięci przez renegatów i rodzimych agentów na szary koniec spraw międzynarodowych”. Odcinając się „od zwyrodnialców z Rady Politycznej”, deklarowali poparcie dla nowego rządu RP na czele z premierem Stanisławem Mackiewiczem, ,przeciw któremu panuje zmowa miernot, zmowa zazdrosnych pismaków

\footnotetext{
${ }^{4}$ J. Z. K[ędzierski], Wnioski, ibidem, s. 13, 14.

5 J. Sokolnicki, Dokąd zmierza Liga Niepodległości Polski?, ibidem, s. 8-12.

${ }^{6}$ Konwent Walki o Niepodległość, ibidem, nr 2/3, s. 12-16. Zob. też: Przeciw odejściu od legalizmu!, ibidem, s. 25, 26.
} 
prowincjonalnych”. Buńczucznie zapowiadano, że rząd Mackiewicza „grać mocno w polityce światowej może i musi""?

Jednak wewnętrzne rozbicie utrudniało czy wręcz uniemożliwiało emigracji „granie” w polityce międzynarodowej. Jeśli — jak uważano — rozwiązanie sprawy polskiej uzależnione było przede wszystkim od sytuacji międzynarodowej, powinno to skłaniać emigrantów do uporządkowania wewnętrznych problemów. Tak się jednak nie stało. Zmarnowano jedyny potencjalny atut — jedność działania, a przepaść między antagonistycznymi ośrodkami stała się jeszcze większa niż w chwili podejmowania akcji zjednoczeniowej. Im bardziej się kłócono, tym mniej politycy emigracyjni znaczyli. I na odwrót: im mniej znaczyli, tym bardziej się kłócili. To złowieszcze sprzężenie jak fatum zawisło nad ,polskim” Londynem. Emigracyjny rząd, już od dawna ignorowany na arenie międzynarodowej, w połowie lat pięćdziesiątych przestał być poważnie traktowany nie tylko przez uchodźczą elitę, ale i emigracyjne masy.

W ciągnącym się od kilku lat sporze o prezydenturę kluczowego znaczenia nabierała postawa generała Władysława Andersa. Generalny inspektor sił zbrojnych wyrósł na arbitra i nieformalnego przywódcę emigracji. Doceniając autorytet i społeczne poparcie, jakim się cieszył, ,zamkowi” przeciwnicy zjednoczenia zabiegali o pozyskanie go dla swoich planów. O byłym dowódcy II Korpusu Polskiego w patetycznym tonie pisał publicysta „Monitora Londyńskiego”: „Dziś na całym świecie — twierdził Nike — jest znane nazwisko Generała Andersa, jako symbol walki żołnierza polskiego. Na dźwięk tego nazwiska żywiej bije każde patriotyczne serce polskie w Kraju i drży karabin w rękach żołnierza-Polaka, gdy defiluje przed Belwederem, zajętym przez zdrajców i okupantów. Na dźwięk tego nazwiska swój i obcy pamięta o kampanii polskiej we Włoszech, w Niemczech, Francji i Holandii i o lotnictwie polskim w wojnie o zwycięstwo nad Niemcami Hitlera [...] Z nazwiskiem Generała Andersa łączy się nierozerwalnie przeszłość i przyszłość wojenna Polski”. „Zamkowy” publicysta przekonywał, że zabiegi rozmaitych intrygantów, zmierzających do przeciągnięcia Andersa na stronę obozu ,zjednoczenia”, skazane były na porażkę

Wobec niechęci generała Sosnkowskiego do „rewolucyjnych” działań redaktor „Monitora Londyńskiego" nie tracił nadziei na odciągniecie go od obozu „zjednoczenia”. Kędzierski pytał niedoszłego zjednoczyciela emigracji ,z kim i dokąd” zamierza iść. Przekonywał Sosnkowskiego, że powinien przekreślić Akt zjednoczenia oraz odciąć się od „bergowców” z Rady Politycznej i „renegatów piłsudczyzny” z LNP: „Czas oprzeć się nie na degeneratach politycznych - twierdził, nie przebierając w słowach — ale na masach żołnierskich, swej przysiędze wiernych. Sytuacja polityczna dziś nie pozwala na żadne kłamstwa zjednoczeniowe. Wyrasta armia niemiecka i jutro agenci z Rady Politycznej gotowi wziąc pieniądze z Niemiec. Z nimi nie zajdzie Pan do wolnej Polski. Trzeba pogrzebać tego bękarta martwo urodzonego, jakim jest Akt Zjednoczenia i bez żadnej sofistyki stanąć tam, gdzie każdy prawy Polak w walce o wolną Ojczyznę stanąć musi”, czyli przy prezydencie Zaleskim ${ }^{10}$. Sosnkowski nie zamierzał jednak dołączyć do pogrążającego się w politycznej izolacji ośrodka prezydenckiego. Chcąc ocalić legalizm i zjednoczenie (co okazało się niemożliwe), nie opowiedział się jednoznacznie po żadnej ze stron i powrócił do Kanady.

Niebawem ,zamek” spotkało kolejne niepowodzenie. 4 VIII 1954 r. posłuszeństwo prezydentowi wypowiedział generał Anders, który do tej pory trwał przy Zaleskim. Generalny

\footnotetext{
${ }^{7}$ Sprawa najważniejsza, ibidem, s. 1-3.

${ }^{8}$ Szerzej zob. K. Tarka, Emigracyjna dyplomacja. Polityka zagraniczna rządu RP na uchodźstwie 1945-1990, Warszawa 2003.

${ }_{9}$ Nike, Przyszłość generała Andersa, „Monitor Londyński” 1954, nr 2/3, s. 3-5.

${ }^{10}$ J. Z. K[ędzierski], Z kim i dokąd Panie Generale?, ibidem, s. 6-12.
} 
inspektor sił zbrojnych w liście do prezydenta zarzucił mu łamanie konstytucji, niedotrzymanie ,podstawowych zobowiązań o charakterze prawno-państwowym” (,umowy paryskiej" i własnej deklaracji o ustąpieniu), brak społecznego zaufania oraz podstaw moralnych i politycznych do dalszego pozostawania na urzędzie prezydenta. „Po głębokim rozważeniu wytworzonej sytuacji — podkreślił Anders — stwierdzam, że nie może Pan wykonywać obowiązków Prezydenta Rzeczypospolitej i - zgodnie z nakazem sumienia oświadczam, że przestałem uważać Pana jako Prezydenta Rzeczypospolitej i Zwierzchnika Sił Zbrojnych" "11

Zaleski jeszcze tego samego dnia odpowiedział pismem zwalniającym Andersa ze stanowiska generalnego inspektora sił zbrojnych: „Przykro mi — stwierdził prezydent — że tak zasłużony żołnierz splamił się w obliczu pokoleń potomnych, buntem wobec swoich legalnych władz, uzurpując sobie prawa, które tak z obowiązujących przepisów prawnych, jak i z dobrych obyczajów politycznych do niego nie należą"12.

Chcąc zdyskredytować przeciwników prezydentury Augusta Zaleskiego, redakcja „Monitora Londyńskiego” cały kolejny numer poświęciła odsłonięciu kulis „rokoszu”. Józef Godlewski, długoletni prezes Związku Ziem Wschodnich oraz prezes Rady Naczelnej Konwentu Walki o Niepodległość, w liście otwartym do generała z 6 sierpnia zarzucił mu bezprecedensową „napaść na swego zwierzchnika, w tym wypadku Prezydenta RP”, i ,proklamowanie własnej niezależności, więcej — dyktatury". Godlewski oskarżył Andersa o złamanie konstytucji i przysięgi żołnierskiej: „Zamiast stać w obronie Zasad i Symboli, Pan Generał, który dostąpił wielu zaszczytów i honorów pozwolił sobie podeptać to wszystko, znieważyć nasze najlepsze tradycje i Zasady oraz postawił siebie poza nawiasem praworządności”. Zarzucił również Andersowi, że swym postępowaniem przyczynił się do zaostrzenia sporów, do pogłębienia podziałów w „,polskim” Londynie ${ }^{13}$.

„Niegodny postępek” generała Andersa 7 sierpnia ,jak najsurowiej” potępiła Rada Naczelna i Komitet Wykonawczy Konwentu Walki o Niepodległość. Niezłomni obrońcy „,zamku” podkreślali, że Anders, wypowiadając posłuszeństwo prezydentowi, ,popełnił czyn niegodny honoru Żołnierza Polskiego, a sprawie walki o Niepodległość zadał od czasu Jałty cios najbardziej dotkliwy"

W obszernym artykule Kędzierski demaskował działalność „rokoszan” w ostatnich latach. „Zamkowy” publicysta piętnował ,agenturalne, płatne przez obcych partie z Rady Politycznej, splamione aferą Bergu”. O stronniczość i manipulację w przedstawianiu wydarzeń oskarżył „,prasę w języku polskim w Wielkiej Brytanii”, na czele z londyńskim „Dziennikiem Polskim”. Nie oszczędził też generała Andersa, któremu zarzucił zdradę, złamanie przysięgi żołnierskiej, wybujałe ambicje: „Sumienie generała Andersa, gdy zniszczył swój honor i nie wykonał rozkazu, pełne jest hańby!". Nadzieję pokładał w prezydencie Zaleskim: „Ten człowiek — pisał Kędzierski — kieruje naszą walką, w której jedynie zdrada zniszczyć nas może, zdrada rodzima, nie zdrada obcych. Obca zdrada osłabia, ale serca nie tyka, dzieje się poza nami. Zniszczyć nas może tylko zdrada rodzima"15.

\footnotetext{
${ }^{11}$ Materiaty do dziejów polskiego uchodźstwa niepodległościowego 1939-1991, t. VII, Wybór dokumentów do dziejów polskiego uchodźstwa niepodlegtościowego 1939-1991, oprac. i red. A. Suchcitz, L. Maik, W. Rojek, Londyn 1997, s. 310.

${ }_{12}$ Pismo Prezydenta Rzeczypospolitej do gen. W. Andersa, „Monitor Londyński” 1954, nr 4/5, s. 3.

${ }^{13}$ List senatora J. Godlewskiego do gen. W. Andersa, ibidem, s. 5-7.

${ }^{14}$ Uchwała Rady Naczelnej i Komitetu Wykonawczego Konwentu Walki o Niepodległość w sprawie generała Władystawa Andersa, ibidem, s. 21.

${ }_{15}$ J. Z. K[ędzierski], Zdrada jedności narodowej, ibidem, s. 7-21.
} 
W trudnej sytuacji finansowej, w jakiej znalazł się „zamek”, redakcja „Monitora Londyńskiego" apelowała do ,,polskich patriotów i prawdziwych niepodległościowców” o wpłaty na fundusz wydawniczy: „Pismo nasze — podkreślono — jest niezależne i nie jest przez nikogo subsydiowane. Istnienie jego, w naszej ocenie, jest konieczne dla rzeczowego bezstronnego naświetlania sytuacji politycznej i walki o najżywotniejsze sprawy Państwa Polskiego"16.

„Monitor Londyński” okazał się efemerydą. Po wydaniu zaledwie trzech zeszytów pismo upadło. Dziś jest zupełnie zapomniane i nieznane nawet badaczom zajmującym się powojenną emigracją polityczną. Jakie były dalsze losy jego redaktora oraz wydawcy?

Jerzy Z. Kędzierski szybko wycofał się z życia politycznego emigracji. Marginalizacja obozu ,zamkowego", rozczarowanie polityką Zachodu oraz liberalizacja systemu komunistycznego w kraju w roku 1956 sprawiły, że emigracyjna polityka straciła dla niego sens. Swoją przyszłość wiązał z krajem. Do Polski po raz pierwszy przyjechał w odwiedziny w 1958 r. Jego pasją była historia Anglii (na przełomie lat czterdziestych i pięćdziesiątych studiował historię w University of London). Pracował nad książką na ten temat, którą planował wydać po powrocie do Polski. Marzył też o pracy naukowej na jednym z krajowych uniwersytetów. W końcu 1957 r. kontakt z Kędzierskim nawiązał pracownik Konsulatu Generalnego PRL w Londynie Mieczysław Kowalski (w rzeczywistości oficer wywiadu). W rozmowach z kapitanem Kowalskim Kędzierski z lekceważeniem wypowiadał się o ,zamkowych” politykach. Uważał ich za nieszkodliwych maniaków, ,z którymi czas zrobi swoje”. Z atencją mówił jedynie o prezydencie Zaleskim. W następnych latach wielokrotnie spotykał się z funkcjonariuszami wywiadu. Za przekazywane informacje otrzymywał wynagrodzenie. Jako działacz polonijny był wiceprezesem ,prokrajowego" Centralnego Komitetu Tysiąclecia Państwa Polskiego w Wielkiej Brytanii. Ze względu na „bezużyteczność kontaktu” w 1965 r. został wyeliminowany z sieci agenturalnej. W latach sześćdziesiątych współpracował z tygodnikiem „Kronika”, redagowanym przez Bolesława Świderskiego, znanego w ,polskim” Londynie wydawcę i księgarza (pismo finansował wywiad PRL). Na łamach „Kroniki” drukował przeważnie opowiadania, wiersze oraz artykuły o tematyce historycznej. Redagował również rubrykę „TAM”, w której przedstawiał wydarzenia w kraju. W 1974 r. wrócił na stałe do Polski, gdzie zmarł w połowie lat osiemdziesiątych ${ }^{17}$.

W ramach obozu ,zamkowego” karierę polityczną zrobił natomiast wydawca „Monitora Londyńskiego". Jerzy Ścibor (prawdziwe nazwisko Kamiński) był jednym z wiceprezesów I i II Rady Rzeczypospolitej Polskiej (1954-1963), zasiadał również w III Radzie RP (1963-1968). W rządach Hugona Hankego (1955) i Antoniego Pająka (1955-1957) był ministrem spraw wewnętrznych, a w rządzie Aleksandra Zawiszy (1965-1966) ministrem spraw krajowych. W latach 1955-1960 wchodził w skład Komisji Głównej Skarbu Narodowego RP. W 1967 r. na skutek wylewu krwi do mózgu wycofał się z życia politycznego. Zmarł w Londynie w 1990 r. w wieku osiemdziesięciu czterech lat ${ }^{18}$.

\footnotetext{
${ }^{16}$ Fundusz wydawniczy Monitora, ibidem, s. 22.

${ }^{17}$ Biogramy J. Z. Kędzierskiego w: Mały słownik pisarzy polskich na obczyźnie 1939-1980, red. B. Klimaszewski, Warszawa 1992, s. 157; Współcześni polscy pisarze i badacze literatury. Słownik biobibliograficzny, red. J. Czachowska, A. Szałagan, t. IV, Warszawa 1996, s. 106, 107. Zob. też Archiwum Instytutu Pamięci Narodowej, 01069/655. W 1965 r. londyńska Oficyna Poetów i Malarzy wydała książkę Kędzierskiego Historia Anglii, t. I, Do roku 1485, rok później pod tytułem Dzieje Anglii do roku 1485 ukazała się ona również nakładem wrocławskiego Ossolineum. W 1986 r. Ossolineum wydało pośmiertnie jego dwutomowe Dzieje Anglii 1485-1939. Szerzej zob. K. Tarka, Emigrant w sieci tajnych stużb. Przypadek Jerzego Zdzisława Kędzierskiego, „Glankopis” 2012, nr 27, s. 115-124.

${ }^{18}$ Biogram J. Ścibora-Kamińskiego w: M. Gałęzowski. Ludzie konspiracji piłsudczykowskiej 19391947, Warszawa 2006, s. 717-724. Zob. też: B. Penciak, Saga o Jerzym Stanisławie Ściborze-Kamińskim, Warszawa 2000.
} 
Konwent Walki o Niepodległość nie odegrał większej roli na emigracyjnej scenie politycznej. Organizacja przeżyła dwa rozłamy. W 1963 r. wyodrębnił się z niego Ruch Odrodzenia Narodowego z Juliuszem Sokolnickim na czele, a w 1971 r. Bronisław Łokaj stworzył Związek Legalistów Polskich ${ }^{19}$.

\section{„Monitor Londyński” — the Brief Life of a Periodical Issued by the „Castle” Legalists}

The first issue of „Monitor Londyński” was published at the beginning of July 1954 during an apogee of a controversy concerning the Polish Presidency in exile. The periodical, edited by Jerzy Zdzisław Kędzierski and published by Jerzy Ścibor, both active members of the pro-Presidential Convent of a Struggle for Independence, was announced as a bi-weekly issued by uncompromising defenders of legalism and sincere supporters of President August Zaleski (the „Castle” legalists). The editorial board attacked opponents of the Zaleski Presidency in the Political Council and condemned General Władysław Anders for opposing the Zaleski Presidency. Ultimately, „Monitor Londyński” turned out to be ephemeral and only three fascicles were published. Today, it is totally forgotten even by researchers studying post-war political émigré circles.

The marginalisation of the „Castle” camp (the adherents of President Zaleski), disappointment in the policy of the West, and the liberalisation of the communist system in Poland after 1956 became the reasons for the withdrawal of J. Z. Kędzierski from political life in exile. Avidly interested in English history, he worked on a study dealing with this topic, which he planned to publish upon his return to Poland. At the end of 1957 Mieczysław Kowalski, an employee of the General Consulate of the People's Republic of Poland in London (actually, an Intelligence officer), established contact with Kędzierski, who in subsequent years frequently met with Intelligence functionaries and received payments for information concerning the émigré milieu. Kędzierski returned to Poland in 1974 and died there in the mid-1980s.

On the other hand, Jerzy Ścibor enjoyed a political career within the „Castle” camp. He held the post of minister of internal affairs in the cabinet of Hugo Hanke (1955) and Antonio Pająk (1955-1957), and of minister for home affairs in the cabinet of Aleksander Zawisza (1965-1966). Died in London in 1990.

\footnotetext{
${ }_{19}$ A. Adamczyk, Piłsudczycy w izolacji (1939-1954). Studium z dziejów struktur i myśli politycznej, Bełchatów 2008, s. 584.
} 